\title{
The Defence of Illegality in Private Law
}

\author{
Nathan Tamblyn ${ }^{1}$ (D)
}

Accepted: 24 September 2021 / Published online: 6 October 2021

(c) The Author(s) 2021

\begin{abstract}
The defence of illegality is invoked across private law, but has a reputation for being confused. This article argues that the defence can be rendered intelligible and sharply focused by understanding its underlying rationale, and applying that discretely and to different effect in each of tort, contract, unjust enrichment, and trusts.
\end{abstract}

Keywords Illegality $\cdot$ Defence $\cdot$ Tort $\cdot$ Contract $\cdot$ Unjust enrichment $\cdot$ Trusts

Broadly put, the defence of illegality means that a claim can be defeated if it involves the claimant's own illegal conduct. The defence is invoked across private law, and we shall consider its application in tort, contract, unjust enrichment, and trusts. The defence has a reputation for being confused and confusing. The Law Commission issued no fewer than three consultation papers on the illegality defence, ${ }^{1}$ before concluding that, ${ }^{2}$ aside from trusts, no proposals were needed since, in its view, the law was moving in the right direction with Gray $v$ Thames Trains Ltd. ${ }^{3}$ That case was subsequently endorsed by Henderson. ${ }^{4}$ This article is critical of both those cases. As for trusts, the Law Commission recommended legislative change, but the government put aside the proposals. ${ }^{5}$ Since Gray, the defence of illegality has been to the

1 CP No 154, Illegal Transactions: The Effect of Illegality on Contracts and Trusts (1999); CP No 160, The Illegality Defence in Tort (2001); CP No 189, The Illegality Defence (2009).

2 Law Com No 320, The Illegality Defence (2010).

3 [2009] UKHL 33.

${ }^{4}$ Henderson v Dorset Healthcare University NHS Foundation Trust [2020] UKSC 43.

5 March 2012: https://www.lawcom.gov.uk/project/illegality/.

With thanks for their helpful comments to: Richard Edwards, Timon Hughes-Davies, Christina Walton, and the anonymous reviewer.

Nathan Tamblyn

n.tamblyn@exeter.ac.uk

1 University of Exeter Law School, Exeter, UK 
Supreme Court at least seven times, ${ }^{6}$ whose judgments have not spoken with one voice. There is still need for clarity.

The defence of illegality is expansive. By focusing on core areas, we are able to make headway. In this article, we shall mainly be concerned with two-party situations where the claimant has contravened the criminal law. This article argues as follows. First, there is only one persuasive rationale for the defence of illegality. Other rationales suggested in the case law are implausible, irrelevant or redundant. Further, that one rationale can be given greater specificity than is currently the case. Second, the current formulation of the defence of illegality purports to apply to all civil claims across the board, and as a result is too vague to provide useful advance guidance. The singular rationale ensures that the defence of illegality has coherence, but beyond that, we should acknowledge that one size does not fit all. Rather, different formulations of the defence are better suited to different areas of law. These different formulations also allow for much greater specificity and thus predictive certainty.

This article will proceed, first, by setting out the current approach to the defence of illegality, then by taking each area of law in turn. The conclusion draws it all together.

\section{The Current Approach}

The founding case for the modern approach to the defence of illegality is Patel $v$ Mirza. ${ }^{7}$ It was a claim in unjust enrichment, and we will consider the facts of the case in the section on unjust enrichment below. For present purposes, we can confine ourselves to the principles articulated in the case.

The first judgment was given by Lord Toulson JSC, with whom a majority agreed, and it is his judgment which has been emphasised in subsequent cases. He said that the defence of illegality involved a trio of considerations ${ }^{8}$ : (a) the underlying purpose of the prohibition which has been transgressed, and whether it would be enhanced by denying the claim; (b) whether any other public policies would be rendered less effective by denying the claim; (c) whether denying the claim would be a proportionate response to the illegality.

Lord Toulson's approach was endorsed and applied in Stoffel \& Co v Grondona, ${ }^{9}$ and Henderson $v$ Dorset Healthcare University NHS Foundation Trust. ${ }^{10}$ (We will consider the facts of those two cases in the tort section below.) Along with Patel, these are the three most recent cases on the defence of illegality in the Supreme

\footnotetext{
${ }^{6}$ Hounga $v$ Allen [2014] UKSC 47; Les Laboratoires Servier v Apotex Inc [2014] UKSC 55; Bilta (UK) Ltd v Nazir (No 2) [2015] UKSC 23; Patel v Mirza [2016] UKSC 42; Singularis Holdings Ltd v Daiwa Capital Markets Ltd [2019] UKSC 50; Stoffel \& Co v Grondona [2020] UKSC 42; Henderson v Dorset Healthcare University NHS Foundation Trust [2020] UKSC 43.

7 [2016] UKSC 42.

8 [2016] UKSC 42, [101], [120].

9 [2020] UKSC 42.

10 [2020] UKSC 43.
} 
Court. Henderson also confirmed explicitly that the test in Patel should be seen as applicable, not just to claims in unjust enrichment, but across civil law generally. ${ }^{11}$

However, Henderson also expanded on Lord Toulson's approach. In Patel, Lord Toulson's first consideration was, to repeat, the underlying purpose of the prohibition which has been transgressed. ${ }^{12}$ But in Henderson, the court said that the first consideration should not be so confined. ${ }^{13}$ Two other policy considerations were suggested. First, whether public opinion would disapprove the result, thus bringing the law into disrepute. ${ }^{14}$ Second, the defence of illegality should be used as a deterrent against crime. ${ }^{15}$ (We return to these points in the tort section below.)

As for the original trio of considerations themselves, the principal criticism is that they are so general as to provide little substantive guidance but plenty of uncertainty. In particular, consideration (b), and its reference to any other public policy, seems especially expansive and unguided. What is more, consideration (c) comes with a further indicative (but non-exhaustive) list of sub-considerations: the seriousness of the conduct; the centrality of the conduct to the contract; whether the conduct was intentional; whether there was a marked disparity in the parties' respective culpability. ${ }^{16}$ So we have the potential for considerations upon considerations. And all this is compounded if, as in Henderson, the court continues to add further policy concerns into the mix beyond those originally identified by Lord Toulson.

Lord Toulson himself sought to meet the criticism of uncertainty head on, ${ }^{17}$ but his response was unconvincing. ${ }^{18}$ For example, to say that the previous law was also uncertain is hardly a commendation for this new approach. And to say that parties contemplating criminal behaviour need or are entitled to less guidance seems quite the opposite; parties should know precisely where the line is, and what the consequences are, for criminal behaviour.

There is no need to suffer these weaknesses when there is a better approach. The trio of considerations are so wide because they purport to apply to all civil claims across the board. If instead we acknowledge that one size does not fit all, then we can formulate (different) sharp-edged concrete tests in each of tort, contract, unjust enrichment, and trusts. We will identify those formulations below.

As for an underlying rationale to the defence of illegality, Lord Toulson said in Patel that there were two reasons for the defence ${ }^{19}$ : law should be coherent and not self-defeating, 'condoning illegality by giving with the left hand what it takes with the right hand'; and a person should not be allowed to profit from their own

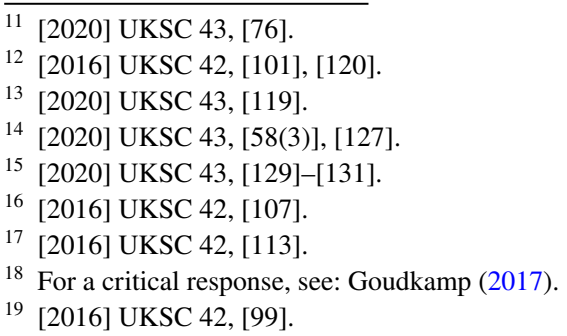


wrongdoing. However, he then immediately suggested that this latter reason lacked explanatory power and provided poor guidance. ${ }^{20}$

In Stoffel, the court said that the trio of considerations is directed at determining whether there might be inconsistency damaging to the integrity of the legal system. ${ }^{21}$ In other words, the court stressed the rationale that the law should be coherent and not self-defeating. The rationale of preventing someone from profiting from their own wrong was not given as a separate justification. Rather, it was characterised as merely an example of the law not being self-defeating: 'for one branch of the law to enable a person to profit from behaviour which another branch of the law treats as criminal...would tend to produce inconsistency... and so cause damage to the integrity of the legal system'. ${ }^{22}$ To put the matter beyond doubt, the court said that the notion that no-one should profit from their wrong is "no longer the true focus of the inquiry', not least because it lacks explanatory power. ${ }^{23}$

This clarification is to be welcomed. When we seek to apply the defence in specific context below, we will find the rationale, that no-one should profit from their own wrong, to be irrelevant or redundant. And yet, in Henderson, the rationale of not profiting from one's wrong appears to have been re-introduced. ${ }^{24}$

In summary, the problems with the current approach is that the trio of considerations are vague and non-exhaustive, with further considerations being added. Also, that one proffered rationale, of not profiting from one's wrong, has an uncertain status, as well as being questionable in itself.

There is something to salvage. I agree with the rationale that the law should be coherent and not self-defeating. That is also the one preferred by the Law Commission. ${ }^{25}$ But I would suggest that we can be more specific still (and specifics provide better guidance than generalities): if conduct is proscribed by the criminal law, then private law should not enforce that conduct, or reward it with payment. What is more, although I will suggest below separate tests for illegality in different areas of law, all of them will be underpinned by this singular rationale, thus retaining that level of theoretical coherence. Indeed, it is this rationale, in its more specific formulation, which informs what those different concrete tests should be, as we will see.

\section{Tort Law}

To repeat, if the law is to be coherent and not self-defeating, then, if conduct is proscribed by the criminal law, private law should not enforce that conduct, or reward it with payment. That is the best rationale for the defence of illegality. But with this

\footnotetext{
20 [2016] UKSC 42, [100]-[101].

21 [2020] UKSC 42, [23], [26].

22 [2020] UKSC 42, [33].

23 [2020] UKSC 42, [46].

24 [2020] UKSC 43, [119], [121]. All the judges from Stoffel also heard Henderson, but judgment in Henderson was given by a different (additional) judge, and Stoffel was not cited.

25 CP No 160, The Illegality Defence in Tort (2001), [7.9].
} 
is mind, it is difficult to see when the defence would ever apply in tort law, at least in circumstances where the tort claimant is seeking compensation for harm suffered.

This point is demonstrated clearly by Revill $v$ Newbery. ${ }^{26}$ In that case, the claimant burglar successfully sued the property owner for injuries inflicted by the owner on the burglar. Although the criminal law proscribes burglary, and so the claimant was in contravention of the criminal law, that did not allow the property owner to transgress the tortious rights of the claimant. There is no inconsistency in the criminal law proscribing burglary, and tort law proscribing the negligent infliction of harm, even upon burglars.

Similarly, in Stoffel \& Co v Grondona, ${ }^{27}$ the claimant bought a house pursuant to a mortgage fraud, and the defendant solicitors negligently failed to convey the house to her or register the interest of the bank. When the fraud unravelled, the bank could not repossess the house, and sued the claimant personally for the debt. She successfully sought to be compensated in that amount by the solicitors. Again, there was no inconsistency in the criminal law proscribing fraud, and tort law proscribing the negligent infliction of financial loss, even upon fraudsters.

And yet a number of leading tort law cases discuss the defence of illegality. We will now consider them, for two reasons. First, some of them propose alternative rationales for the defence. We will see why those alternatives are unpersuasive. Second, to the extent that the outcomes of those cases were attractive, ${ }^{28}$ nevertheless they can be properly reached by means other than a defence of illegality. In particular, there are suitable defences of contributory negligence and volenti.

Thus we shall consider: (i) Henderson, with its additional considerations beyond Patel, and its endorsement of Gray $v$ Thames Trains, which itself proposes the (unnecessary) division of the defence of illegality into narrower and wider versions - and when neither case needed to invoke the defence of illegality anyway; (ii) the alternative (inapplicable) rationale that one should not profit from one's wrong; and (iii) Pitts $v$ Hunt, and the (false) assertion that illegality precludes us from determining a standard of care.

(1) In Henderson $v$ Dorset Healthcare University NHS Foundation Trust, ${ }^{29}$ the claimant stabbed her mother to death. She pleaded guilty to manslaughter on the grounds of diminished responsibility and was detained in a secure hospital. She had a history of schizophrenia with paranoia, and at the time of the killing was under the care of the defendant NHS trust. She sued the trust in negligence for failing to return her to hospital when her condition deteriorated, arguing that this would have prevented the killing. She sought damages including for loss of liberty. The trust admitted negligence, but successfully defended the claim by invoking the defence of illegality.

\footnotetext{
26 [1996] QB 567 (CA).

27 [2020] UKSC 42.

28 The Law Commission did note that, while the reasoning might have been questionable, most cases did produce just outcomes: Law Com No 320, The Illegality Defence (2010), [3.8].

29 [2020] UKSC 43.
} 
The judgment in Henderson was delivered by Lord Hamblen JSC. It applied Lord Toulson's trio of considerations approach from Patel. But in doing so, it also reintroduced ideas from the earlier case of Gray $v$ Thames Trains Ltd. ${ }^{30}$ Indeed, a significant amount of the judgment was given over to the questions of whether Gray could be distinguished (the answer was no), ${ }^{31}$ and whether the approach in Gray was compatible with the approach in Patel (the answer was yes). ${ }^{32}$ Lord Hamblen said that Patel was no 'year zero', and that previous case law of precedential value, like Gray, should continue to be applied. ${ }^{33}$ Thus we need to consider Gray to see how its ideas were incorporated into Henderson.

In Gray, the claimant was a passenger on a train involved in a major railway accident as a result of the defendant's negligence. This caused the claimant to suffer post-traumatic stress disorder (PTSD), under the influence of which he killed a man. The claimant was convicted of manslaughter on the grounds of diminished responsibility. He sought to sue the defendant for damages including loss of liberty. This was defeated by the defence of illegality.

Lord Hoffmann in Gray suggested a narrower and wider version of the defence. The narrower version was this: a claimant cannot recover for damage which is the consequence of a sentence imposed by the court for a criminal act. ${ }^{34}$ But in my view, there is no need to characterise this as a defence of illegality, for the following reasons.

There is only need to invoke a defence if the cause of action is otherwise made out. In a case such as Gray, the better view is that the cause of action is not made out. What caused the loss of liberty? The court imposing a detention order. The detention followed from the claimant's conviction for a crime with mens rea. (This was not a case of insanity or automatism, for example.) The crime was attributable to the PTSD. This in turn was brought about by the train accident. The train accident was caused by the defendant's negligence. At this point, the defendant's negligence is five steps removed. It is far too remote to be actionable. Put another way, it was not a foreseeable consequence of the defendant's negligence that the claimant would commit manslaughter.

Put yet another way, the claimant's decision to commit manslaughter was an intervening act. For example, in $R v$ Kennedy, ${ }^{35}$ the defendant was not guilty of manslaughter when the victim overdosed on heroin supplied by the defendant. It was the victim's own autonomous decision to inject which caused his death and broke the chain of causation. (The defendant was convicted for supplying drugs.) Similarly, in Gray, it was the claimant's own autonomous decision to kill.

We might have sympathy for the claimant in Gray, because past events changed his character. However, there are many possible influences which might lead

\footnotetext{
30 [2009] UKHL 33.

31 [2020] UKSC 43, [58]-[59], [79]-[86].

32 [2020] UKSC 43, [89]-[96], [145].

33 [2020] UKSC 43, [77], [145].

34 [2009] UKHL 33, [29]-[50].

35 [2007] UKHL 38.
} 
someone to commit crime, including disadvantaged upbringing and social conditions. These do not ordinarily provide the accused with a defence, or a cause of action for an indemnity. In this context, the criminal law is premised on the idea that an accused can properly be held accountable for actions they take intentionally or recklessly. An extreme example of this is $R v$ Kingston. ${ }^{36}$ In that case, the accused sexually abused a boy. The accused was drugged, unknowingly, by another person who intended thereby to provoke this very behaviour so as to blackmail the accused. Still, the accused was found guilty, because he had formed the mens rea to commit the abuse.

In Gray, Lord Hoffmann said that the wider version of the defence of illegality was this: a claimant cannot recover for damage which is the consequence of their own criminal act. ${ }^{37}$ This, said Lord Hoffmann, was justified on the basis that it would be offensive to public notions of the fair distribution of resources that a claimant be compensated for the consequences of their own criminal conduct. ${ }^{38}$ But there are two problems with this rationale.

The first problem is vagueness. The defence is said to be based on (i) causing offence, whatever that means, and why it should matter, to (ii) public notions, whoever that public is, and where they get their notions from, of (iii) fair distribution of resources, about which I doubt there is any consensus, if the public have ever given it that much thought at all. These are big concepts, and they are not at all explained or justified.

The second problem, admitted by Lord Hoffmann, is that the wider test leads to problems of causation. ${ }^{39}$ Lord Hoffmann thought it boiled down to this ${ }^{40}$ :

Can one say that, although the damage would not have happened but for the tortious conduct of the defendant, it was caused by the criminal act of the claimant? ... Or is the position that, although the damage would not have happened without the criminal act of the claimant, it was caused by the tortious act of the defendant?

Now, in negligence cases, causation must be proven to establish a cause of action. Only once a cause of action is made out will a defence be engaged. And I have suggested above, with Gray, that remoteness, or an intervening act, prevent us from ever getting as far as discussing the illegality defence in that case. So Lord Hoffmann is right to recognise that causation can have a relevant role to play. But the above quotation is confusing indeed. For a start, it seeks to contrast the 'but for' question with the test of causation, when the 'but for' question is usually taken to be part of the test of causation. ${ }^{41}$

\footnotetext{
36 [1995] 2 AC 355 (HL).

37 [2009] UKHL 33, [29].

38 [2009] UKHL 33, [51].

39 [2009] UKHL 33, [51].

40 [2009] UKHL 33, [54].

${ }^{41}$ For example, see: Jones \& Dugdale (2020) at para [2.09].
} 
Glofcheski (1999: 10) gives the example of the jay-walking pedestrian injured by a careless driver. It would defy common sense, if we apply Lord Hoffmann's above dichotomy, to say that the injury was caused either by the pedestrian's illegal behaviour, or by the driver. More naturally we would say that both are to blame. And it is precisely such situations where contributory negligence (rather than illegality) comes into play.

In summary, as for the narrow approach in Gray, this should not to be characterised as a defence of illegality. Rather, it suggests a fact pattern likely to reveal that the cause of action is not made out because, for example, the outcome is too remote, or was caused by intervening acts. The wider approach is questionable for having an under-developed (and unpromising) rationale, and for relying on unrealistic conceptual distinctions.

This brings us back to Henderson.

Lord Toulson's first consideration in Patel was the underlying purpose of the prohibition which has been transgressed. ${ }^{42}$ But in Henderson, Lord Hamblen said that the first consideration should not be so confined. ${ }^{43}$ He suggested two further policy considerations.

First, Lord Hamblen sought to rehabilitate Lord Hoffmans's claim in Gray about the fair allocation of resources. Lord Hamblen said that allowing a claimant to be compensated for their crime would be an outcome which public opinion would disapprove, thus bringing the law into disrepute. ${ }^{44}$ This, he said, would be so particularly where the compensation was taken from NHS funds. ${ }^{45}$ But this is a dangerous path to tread, allowing the popularity of a decision to influence its outcome.

Second, Lord Hamblen said that the defence of illegality was an important deterrent against unlawful killing. ${ }^{46}$ But this seems particularly ill-suited when the claimants in both Gray and Henderson successfully pleaded diminished responsibility, and so lacked the full mental capacity to weigh their behaviour. At any rate, if the criminal laws of homicide do not deter killing, then a civil law defence is unlikely to do so. Certainly, the Law Commission was not convinced that deterrence was a proper rationale for the defence of illegality in tort law. ${ }^{47}$

So the problems with Henderson are that it followed the approach in Gray, which itself was problematic for the reasons discussed above, and also expanded on the policy considerations in two ways that are unpersuasive and dangerous. And yet, as with Gray, so too with Henderson, there was no need to invoke the defence of illegality. In Henderson, the decision to kill was an intervening act which broke the chain of causation; alternatively the killing, and the following criminal conviction and sentencing, were too remote from, or were not a reasonably foreseeable

42 [2016] UKSC 42, [101], [120].

43 [2020] UKSC 43, [119].

${ }^{44}$ [2020] UKSC 43, [58(3)].

45 [2020] UKSC 43, [127].

${ }^{46}$ [2020] UKSC 43, [129]-[131].

${ }^{47}$ CP No 160, The Illegality Defence in Tort (2001), [7.4]. 
consequence of, the NHS trust's negligence to be actionable. There is no need to invoke the defence of illegality when the cause of action is not made out.

(2) As for not profiting from one's wrong, such a rationale is all but irrelevant in tort law, at least where the tortious claimant is seeking compensation for harm suffered. The Law Commission also thought it an unpersuasive rationale. ${ }^{48}$ This is because such compensation is usually backward-looking. It seeks to cancel out the effects of the tort. Green (2018) refers to this as 'zero sum torts', and says that this is the reason why the defence of illegality can be a conceptual misfit within the law of torts. Unlike contract law, tort law does not usually seek to put the claimant in the position they would have been in had the criminality occurred without mishap. Rather, ordinarily it seeks to return the claimant to the position which they were in prior to the tort. ${ }^{49}$ Indeed, the defence of illegality in Patel $v$ Mirza, ${ }^{50}$ a case of unjust enrichment (discussed below), was similarly rejected precisely because the claimant sought to be returned to their prior position, that is, their position before any attempted criminal activity.

A recent example of this in tort law is again provided by Stoffel \& Co v Grondona. ${ }^{51}$ To repeat, the claimant, who was engaging in mortgage fraud, successfully sued her negligent solicitors for failing to convey the property into her name and register the interest of the mortgagee bank. Because of the solicitors' negligence, when the fraud unravelled, the bank could not repossess the property, so they sued the claimant personally for the debt, in the sum of around $£ 70 \mathrm{k}$. This is the amount which the claimant recovered. ${ }^{52}$ The court was explicit that this was not profit. ${ }^{53}$ Yes, by engaging in the mortgage fraud, the claimant hoped to profit. But she was not asking the court to award her that lost profit. Rather, she had truly bought a property, albeit for fraudulent purposes, and the solicitors' negligence in effect deprived her of the value of that property. She was being compensated for what had been deducted from her existing assets (rather than her projected profit). Similarly, in Revill $v$ Newbery, the burglar was not asking the court to award him the anticipated profits of the theft, but was seeking compensation for the harm inflicted upon his existing assets (his healthy body).

That said, there is a nuance we need to acknowledge here. If a claimant suffers personal injury, they might sue for loss of future earnings. This cannot be recovered if the income would have been earned illegally. ${ }^{54}$ However, properly understood, this derives from the defence of illegality in contract law, at least where the income is earned under a contract. ${ }^{55}$ As we shall see, an illegal contract will not be enforced;

\footnotetext{
48 CP No 160, The Illegality Defence in Tort (2001), [7.5].

49 Livingstone v Rawyards Coal Co (1880) 5 App Cas 25, 39 (Lord Blackburn); Knauer v Ministry of Justice [2016] UKSC 9, [1].

${ }^{50}$ [2016] UKSC 42.

51 [2020] UKSC 42.

52 [2020] UKSC 42, [44].

53 [2020] UKSC 42, [44]-[46].

54 Hewison v Meridian Shipping Services Pte Ltd [2002] EWCA Civ 1821.

55 I think that analogous reasoning would apply if the claimant earned their income, not under a contract, but through criminal behaviour, for example as a burglar. Whether we categorise this analogy under contract or tort law is perhaps a moot point, but the end result would be as follows. A claimant seeking
} 
earnings will not be ordered. This means that there is no loss for tort law to compensate. In other words, illegality in such circumstances is not a defence in tort law, but a defence in contract law, which can mean there is no loss of contractual earnings for tort law to compensate.

(3) In Pitts $v$ Hunt ${ }^{56}$ the claimant was a pillion passenger on a motorcycle ridden by the defendant. Both had been drinking, and the claimant knew the defendant to be unlicensed and uninsured. The claimant encouraged the defendant to ride dangerously. When an accident occurred, the claimant sued for compensation. The defence of illegality was invoked successfully to deny the claimant a remedy.

The reasoning in the judgment lacks clarity. But the court seems to indicate that the defence of illegality is appropriate to cover situations where it is not possible to determine the appropriate standard of care owed by one person to another when both were engaged in a joint criminal enterprise.

This rationale is unpersuasive. We have known since Nettleship $v$ Weston, ${ }^{57}$ that the appropriate standard of care of all road users is that of the reasonable driver. We are not seeking to determine the standard of care of an illegal driver, any more than the standard of care of a novice driver. As Buckley (2015) notes, there would have been no difficulty in identifying the standard of care if a third party (like another driver or pedestrian) had been suing the defendant. Similarly, as Glofcheski (1999: 12) notes, if a burglar cracking open a safe injures another nearby, the standard of care is not that of a burglar, but of any professional locksmith.

In contrast, in Morris $v$ Murray, ${ }^{58}$ the claimant and defendant spent all afternoon drinking before the claimant accepted a flight with the defendant piloting a light aircraft. When it crashed, the claimant sued. There was no difficulty in identifying the standard of care, ${ }^{59}$ but the claim was defeated by the defence of volenti. The court said that the claimant had willingly embarked on the flight, knowing that the defendant was too drunk to discharge his normal duty of care, when the danger was obvious. The claimant had accepted the risk of serious injury.

So Morris v Murray reached the same result as Pitts $v$ Hunt but by the defence of volenti. The trouble in Pitts $v$ Hunt is that the defence of volenti was excluded by statute in a motor vehicle scenario. But it seems wrong to allow that statutory exclusion to be circumvented by the defence of illegality. To say, on the one hand, that consent is no defence to dangerous driving, but on the other hand, that consenting to dangerous driving is a defence, because it makes one a joint criminal, is to engage in a legal sleight of hand, which also seriously undermines the statute.

\footnotetext{
Footnote 55 (continued)

compensation in the tort of negligence for personal injury, for example, is not precluded by the fact that they were, at the time of injury, engaged in criminal behaviour, but they cannot claim loss of future earnings if those earnings would be derived from criminal behaviour.

56 [1991] 1 QB 24 (CA). This was followed in Joyce v O'Brien [2013] EWCA Civ 546.

57 [1971] 2 QB 691 (CA).

58 [1991] 2 QB 6 (CA).

59 For other cases where the court had no difficulty in identifying the tortious standard of care in otherwise criminal conduct, see: $R v$ Wacker [2002] EWCA Crim 1944; Delaney $v$ Pickett [2011] EWCA Civ 1532 .
} 
The message to take from this discussion is as follows. The defence of illegality does not reflect the impossibility of determining the standard of care owed by someone engaged in a criminal activity. Instead, a defence of volenti might be properly available when someone willingly accepts the risks involved in participating in criminal activity. If volenti is negatived by statute, so be it; volenti should not be used, not even under cover of a manipulated defence of illegality or duty of care.

Alternatively, in Pitts $v$ Hunt, the claimant's recovery could have been significantly reduced by the defence of contributory negligence. At first instance, the judge set this at $100 \%$. That was rejected in the Court of Appeal as illogical: the defendant cannot cause an injury which was caused $100 \%$ by the claimant. That logical criticism is sound. But it need not stop the court finding contributory negligence against the claimant, and at a very high percentage.

\section{Contract Law}

The defence of illegality does have a role to play in contract law, at least when the contract claimant engages in criminal behaviour. As Lord Neuberger said in Patel $v$ Mirza ${ }^{60}$ the court should not order specific performance of a criminal act, nor award profits. Again, this is about ensuring consistency between the criminal law and contract law.

Although this rationale is the same in tort law and contract law, nevertheless the different context needs to be noted. For our previous discussion of tort law, the context was the tortious claimant seeking, not the benefit of their criminal act, but compensation for harm suffered during a criminal act, harm which tort law separately proscribes. Whereas in contract law, the contract claimant seeking compensation is usually to be put in the position they would have been in had the contract been carried out. ${ }^{61}$ Where that contract involves criminality, then the contract claimant, contrary to the tort claimant, could be seeking the benefit of their criminal act after all.

This is not to say that contract law should always refuse to enforce contracts which involve criminality however peripheral or incidental. We shall discuss the nuances below. But first, we begin by distinguishing the defence of illegality from three other ideas which are often (unhelpfully) bracketed together with illegality: the doctrine of restraint of trade; contracts not upheld because of immorality (rather than illegality); and statutory interpretation.

(1) The doctrine of restraint of trade should be seen as something in its own right, rather than an example of the defence of illegality. ${ }^{62}$ That doctrine says that contracts in restraint of trade will not be upheld unless they are reasonable to the parties and to the public interest. ${ }^{63}$ The rationale for the doctrine of restraint of trade is to strike a balance. On the one hand, a party might have a legitimate interest in protecting

${ }^{60}$ [2016] UKSC 42, [160].

${ }^{61}$ Robinson v Harman (1848) 154 ER 363, 365 (Parke B).

${ }^{62}$ Harcus Sinclair LLP v Your Lawyer Ltd [2021] UKSC 32, [45].

${ }^{63}$ Thorsten Nordenfelt v Maxim Nordenfelt Guns and Ammunition Co Ltd [1894] AC 535 (HL). 
its investment. For example, the buyer of a business might wish to protect it against immediate competition from the seller-and the seller also gains a higher sale price as a result of that protection. On the other hand, there is a detriment to the seller and society in general if skills idle and productivity is precluded. But all this has nothing to do with preventing inconsistency between criminal law and contract law. In light of this, it does no good to sweep restraint of trade into the defence of illegality, as if the latter were a bin for miscellaneous residual doctrines. They have different rationales, and both will work more honestly if their separate purposes are recognised.

(2) The defence should be restricted to questions of illegality, not immorality. It is unattractive that unelected judges, who form a narrow demographic, should be prohibiting contracts according to their own moral compass. ${ }^{64}$ It also creates a difficult tension between, on the one hand, the common law model of following precedent, which precedent necessarily arises earlier in time, and on the other hand, the reality that moral discussion within society evolves over time. It makes current litigation unpredictable, which strikes at the very heart of the reliability which makes contracts valuable. It has also led to confusion and contradiction in the case law.

For example, a contract to introduce a client to someone with a view to marriage was not enforceable, ${ }^{65}$ but presumably modern dating agency subscriptions are enforceable. After all, the courts now recognise that even a pre-nuptial agreement can be given full effect. ${ }^{66}$ A contract to hire a hall to a group of atheists was not enforceable ${ }^{67}$ but it was possible later to bequeath property to atheists. ${ }^{68} \mathrm{~A}$ contract to hire a carriage to a prostitute is not enforceable, ${ }^{69}$ but a contract of employment for public relations is enforceable even when the employee occasionally procures prostitutes for clients. ${ }^{70}$ And a contract to advertise telephone sex lines is also valid. ${ }^{71}$ As Simon Brown LJ said in the latter case:

It seems to me in the highest degree undesirable that in a case such as this [telephone sex lines], involving as it does an area of human activity habitually regarded as the province of the criminal law, supplemented here by quasigovernmental control... individual judges exercising a civil jurisdiction should seek to impose upon society their own moral attitudes.

Burrows (2020: 230) also doubts whether there should be any continued role for sexual immorality as a basis for the illegality defence in contract. In particular, I suggest, the attitude of the judiciary towards prostitution is shameful. Prostitution is not criminal. And yet the judiciary, historically male, turn their backs on this group of people, usually women, denying them legal protection when some at least are

\footnotetext{
${ }^{64}$ Dworkin (1978: ch 4) said that judges should be concerned with principle, but policy was for the legislature. More generally on the legal proscription of immorality, see Hart (1963).

65 Hermann v Charlesworth [1905] 2 KB 123 (CA).

66 Radmacher v Granatino [2010] UKSC 42.

67 Cowan v Milbourn (1867) LR 2 Exch 230.

68 Bowman v Secular Society Ltd [1917] AC 406 (HL).

69 Pearce v Brooks (1866) LR 1 Exch 213.

70 Coral Leisure Group Ltd v Barnett [1981] IRLR 204 (EAT).

71 Armhouse Lee Ltd v Chappell [1996] Lexis Citation 5306 (CA).
} 
among the most vulnerable in society. ${ }^{72}$ Such official disregard has consequences. For example, when a mass murderer started killing prostitutes, the police were slow to act because the victims were 'non-innocent' or unworthy. It took over 40 years before the police force apologised. ${ }^{73}$

A colleague asks: does this mean that a client could sue a prostitute for breach of contract? The answer is yes, in theory. ${ }^{74}$ (In practice, I doubt that there would be much prostitute-client litigation.) The prostitute who provides a service might sue for non-payment. If the client does not show, the prostitute might sue for lost profits. The client who has paid but gets no service might sue in unjust enrichment, or for breach of contract. Other losses for either party might include travel and accommodation expenses. All of these losses would be routinely recoverable, for example, if it were a contract for a massage or for medical intervention (both of which can be very intimate). None of this would likely lead to specific performance: it has long been orthodox principle that contracts for personal services are not usually specifically enforced. ${ }^{75}$

Some morality is inevitable in contract law. Doctrines like unconscionable bargain demonstrate that quite clearly. But there is a difference between, on the one hand, morality internal to contract law, such as judges seeking to ensure that any contract avoids exploitation, and on the other hand, morality external to contract law, such as judges refusing to deal with contracts whose subject matter makes them feel morally squeamish. The judiciary's sense of subject-matter immorality is not a sound basis on which to do contract law. ${ }^{76}$

(3) When it comes to dealing with statutes, there are two different activities. ${ }^{77}$

One activity is statutory interpretation. In broad terms, statutory interpretation is about identifying the legislator's intention, ${ }^{78}$ and applying rules of construction which, when they point in different directions, must be balanced and weighed. ${ }^{79}$ These rules of construction include consideration of how the suggested interpretation might impact on public policy. ${ }^{80}$

Some statutes are explicit in how they affect contracts. Examples familiar to contract lawyers include the Unfair Contract Terms Act 1977, and the Consumer Rights Act 2015. Less familiar examples might include the Equality Act 2010, s 142, which renders unenforceable any term which constitutes discrimination, and the Surrogacy Arrangements Act 1985, s 1A, which renders surrogacy arrangements

\footnotetext{
72 Home Affairs Select Committee (2016), Prostitution (accessed 13 Jan 2021). For further discussion, see: Kudhail (1999), Primoratz (1993), Moen (2014).

73 BBC News (accessed 13 Jan 2021).

74 Burrows (2020: 230) gives the same answer to a similar example (Example 3).

75 De Francesco v Barnum (1890) 45 Ch D 430, 438 (Fry LJ).

76 A defence of illegality based on immorality also risks violating the principle of legality: it must be possible to determine with reasonable confidence beforehand which acts will attract a sanction. See: Goudkamp (2011: 357).

77 See too the discussion in Henderson at [2020] UKSC 43, [74]-[75].

78 Viscountess Rhondda's Claim [1922] 2 AC 339 (HL), 397 (Lord Wrenbury).

79 Maunsell v Olins [1974] 1 All ER 16 (HL), 18 (Lord Reid).

80 Halsbury's Laws (5 ${ }^{\text {th }}$ edn, 2018) vol 96, para [749].
} 
unenforceable. With other statutes, the effect on contracts might not be explicit. The courts might conclude, for example, that it was not the intention of the legislator to void the contract even though one party has engaged in prohibited conduct. ${ }^{81}$

If a statute explicitly or implicitly voids a contract in certain circumstances, then of course the courts will refuse to enforce the contract, but this is because the courts must apply statute law, not through the grace of a common law defence of illegality. Put another way, if the common law defence of illegality prohibits the enforcement of contracts whose enforcement is prohibited by statute, that reveals a tautology or redundancy to the defence of illegality. And anyway, a common law doctrine could hardly uphold a contract which was prohibited by statute.

The other activity when dealing with statutes, is the defence of illegality proper. It is when a statute prohibits a certain activity, but says nothing about contracts. It is now that the common law doctrine of illegality asks how contract law should respond to the statutory prohibition. It is not about discerning the intention of the legislator, but ensuring that contract law behaves consistently with the prohibition so that the law is not self-defeating. For example, most crimes have a statutory basis. These statutes are usually concerned only with the criminal law, and not with contract law. It is for contract law to develop common law rules to decide what stance to take towards contracts which involve criminal behaviour.

It is important to distinguish these two activities, that is, statutory interpretation and the illegality defence, because they each have different rules. Further, the rules for the defence of illegality apply, not just to statutory crimes, but also to common law crimes (such as murder or manslaughter).

With those preliminaries complete, my suggestion is as follows. The context is where a contract claimant seeks specific enforcement of a contract, or seeks compensation to put them in the same position as if the contract had been performed. In such circumstances, a contract or contract term should be unenforceable if it: (i) requires criminal conduct; or (ii) was created for criminal purposes. Indeed, an agreement to a course of conduct which, if carried out as intended, necessarily involves committing a crime, is itself a crime (of conspiracy). ${ }^{82}$ But beyond these two conditions, criminality should have no impact on the contract-although the criminal law may visit its own consequences on the parties. This approach is clearcut without the need for further unpredictable debate or 'consideration'. It demonstrates a clear link with the rationale for the defence. I shall now seek to explain and defend this suggestion by reference to the case law.

I have suggested that the defence would render the contract unenforceable (rather than void). This is also the suggestion of Burrows (2020). ${ }^{83}$ In particular, this follows from case law recognising that property can still pass under a contract tainted

\footnotetext{
${ }^{81}$ For example, see: Shaw v Groom [1970] 2 QB 504 (CA), where the contract to rent property was upheld, even though the landlord failed to include in the rent book all the details required by legislation.

82 Criminal Law Act 1977, s 1(1).

83 See $§ 44(1)$, and the commentary at p 233.
} 
by illegality, ${ }^{84}$ an outcome which would seem to be inconsistent with characterising the contract as void.

The defence of illegality should apply to criminal conduct. ${ }^{85}$ Thus, if it is a criminal offence to sell fertiliser without a list of ingredients, ${ }^{86}$ then a contract of sale of fertiliser without a list of ingredients will be unenforceable, ${ }^{87}$ at least as against the seller. That latter caveat reflects the point that a claimant should still be able to sue where it was the defendant's contractual responsibility to avoid any criminality. ${ }^{88}$ This is consistent with tort law, where it has also been acknowledged that illegality is no defence when it was the defendant's tortious duty to prevent the criminality. ${ }^{89}$

An example of a contract created for the purposes of criminal conduct is Alexander $v$ Rayson. ${ }^{90}$ That case involved a contract to rent property. The defendant was truly renting property. But rather than produce a genuine contract, the claimant produced two contracts, which misrepresented the true state of affairs, in order to use them to defraud the council of tax. The rental was genuine, but the contracts produced to govern it were shams.

If the contract does not require criminal conduct, or was not created for the purposes of criminal conduct, then any other criminality is incidental or peripheral and should have no impact on the contract. For example, a carrier could sue for freight on cargo carried, even though, when the ship had later taken on bunkers, it was submerged below the load line, for which the master was prosecuted and fined. ${ }^{91}$ In this case, the contract of carriage did not require criminal conduct, nor was it created for criminal purposes. Rather, the criminality happened as a result of actions unrelated to the contract (the later decision to take on too many bunkers). Other familiar examples of contracts which should be enforceable despite background illegality might include: a contract made in an illegally parked car; a courier who could have fulfilled the contract by driving within the speed limit, but who chose to drive dangerously instead; a seller who could have sourced the products lawfully, but instead used a prohibited source.

There are two things that can be said in this context. First, because the criminality is incidental or contingent, it would seem disproportionate to render the contract unenforceable. To repeat, if a contract is concluded in an illegally parked car, it

\footnotetext{
${ }^{84}$ Singh v Ali [1960] AC 167 (PC); Belvoir Finance Co Ltd v Stapleton [1971] 1 QB 210 (CA); Patel v Mirza [2016] UKSC 42, [110]; Stoffel \& Co v Grondona [2020] UKSC 42, [33].

${ }^{85}$ Some case law suggests that contravention of a regulatory prohibition, not just a criminal law, might engage the defence. For example, if it is prohibited by regulations for a solicitor to enter into a fee sharing arrangement, then a contract to share fees will be void: Mohamed v Alaga \& Co [1999] 3 All ER 699 (CA). This case is discussed further below. For present purposes, however, I am focusing on how the defence of illegality in contract law can be sharpened if it is the criminal law which has been contravened.

${ }^{86}$ Fertilisers and Feeding Stuffs Act 1906, s 1(1).

87 Anderson Ltd v Daniel [1924] 1 KB 138 (CA).

${ }^{88}$ Robinson $v$ Ness \& Co [2017] EWHC 2305 (Ch).

${ }^{89}$ Griffin v UHY Hacker Young \& Partners [2010] EWHC 146 (Ch); Singularis Holdings Ltd (in liquidation) v Daiwa Capital Markets Europe Ltd [2019] UKSC 50.

${ }^{90}$ [1936] 1 KB 169 (CA).

91 St John Shipping Corp v Joseph Rank Ltd [1957] 1 QB 267 (QBD).
} 
would seem unduly punitive to deny the contract, when the contract itself is beyond reproach. Lord Toulson's approach in Patel v Mirza does expressly acknowledge the need for proportionality - but only as a consideration to weigh up. In contrast, I am suggesting that it would always be disproportionate to hold a contract unenforceable when the criminality is neither the purpose nor necessary. This cannot be proven through logic, but I suggest that the weight of examples in this section tends towards supporting this conclusion.

Second, allowing the contract to stand in such circumstances does not undermine criminal law. For example, criminal law might prohibit burglary, and contract law might respond by rendering unenforceable a contract to burgle, but there is nothing inconsistent in upholding a contract whereby someone who happens to be a burglar otherwise rents a house, or pays their electricity bill, or shops in the local supermarket.

I have suggested that a contract or contract term be unenforceable for criminality. Thus the defence of illegality could lead to a term being struck out, with the remainder of the contract still enforceable. Again, it is consistent with the case law that a contract might be upheld if only one term is offending and can be severed, as long as what remains after severance does not need to be re-written, is supported by consideration, and where the severance does not change the character of the contract. ${ }^{92}$

Otherwise, the case law is muddled, and it is not possible to reconcile it all. And some miscellaneous areas, if thought to fall within the defence of illegality at all, are bordering on the redundant. The rules of champerty, for example, have been greatly modified by changes to litigation funding arrangements endorsed by statute. ${ }^{93} \mathrm{Nev}-$ ertheless, the case law does contain plenty of examples of sensible outcomes. Thus the defence of illegality renders unenforceable an agreement to smuggle whisky, ${ }^{94}$ or to make a payment in breach of sanctions, ${ }^{95}$ or an agreement not to prosecute / to conceal a crime. ${ }^{96}$ There seems little call for a more discursive approach based on the 'trio of considerations'.

Finally, let us test all this with two more scenarios posed by colleagues.

(1) Emergency repairs must be done to a building, but there has not been sufficient time to obtain parking permits. When the crane parks illegally to save the building, is the contract enforceable? The answer is yes. The contract was not created for the purposes of criminal behaviour, but instead to repair a building. We might also say that the contract does not necessarily require criminal behaviour, because it is possible in theory to repair the building without illegal parking. But let us assume that illegal parking is a practical necessity. The answer actually lies in criminal law.

\footnotetext{
92 Beckett Investment Management Group Ltd v Hall [2007] EWCA Civ 613; Egon Zehnder Ltd v Tillman [2019] UKSC 32. Severance is also acknowledged by Burrows (2020) as a possible response to illegality, at $\$ 44(4)$.

93 Access to Justice Act 1999, Pt II.

94 Foster v Driscoll [1929] 1 KB 470 (CA).

95 Royal Boskalis Westminster NV v Mountain [1999] QB 674 (CA).

96 Mutual Finance Ltd v John Wetton \& Sons Ltd [1937] 2 KB 389.
} 
Because these are 'emergency' repairs, there will be a defence of necessity. ${ }^{97}$ Similarly, it is not tortious when emergency repairs to a dangerous building cause some (not disproportionate) damage to neighbouring property. ${ }^{98}$ With a defence of necessity, there is no criminal behaviour to engage the defence of illegality.

The moral of this story is to trust in criminal law. The purpose of the defence of illegality is to ensure that contract law is consistent with criminal law. It is not there to allow contract lawyers to say that the criminal law is too harsh and so needs contract law to modify it. The purpose of the illegality defence disappears if contract law can subvert criminal law by overruling it. Criminal law often has sufficient sophistication to deal with a range of real-world challenges. But if it is thought that criminal law needs changing, that reform should happen through the proper processes, and not through its subversion in contract law.

(2) X contracts with Y to put money in Y's investment scheme, which makes excellent returns. But $\mathrm{X}$ entered into this contract in order to evade tax. What happens now? First, the contract is unenforceable by X, because it was created for criminal purposes. Next, $\mathrm{X}$ could recover their initial payment in unjust enrichment, as in Patel $v$ Mirza, discussed below. Alternatively, Y might hold the proceeds on trust. ${ }^{99}$ How the illegality defence operates with trusts is also discussed below. (Following my suggestions there, $\mathrm{X}$ would recover the returns, but might face criminal consequences, as well as liability to pay tax.)

\section{The Law of Unjust Enrichment}

For present purposes, it helps to distinguish two contexts in which a claim in unjust enrichment can arise:

(1) In one context, unjust enrichment enables a claimant to get paid for goods or services even though there is no contract, as long as there is an acceptable reason (unjust factor) for that state of affairs. ${ }^{100}$ In these circumstances, the illegality defence in unjust enrichment can follow the approach of contract law. Once again, the law should be consistent: if behaviour is proscribed by the criminal law, the restitutionary claimant should not get paid for carrying out that behav-

\footnotetext{
97 For example, there can be a defence of necessity when driving over the speed limit to get an injured child to hospital: DPP v Pipe (2012) EWHC 1821 (Admin).

98 Dewey $v$ White (1827) M \& M 56, 173 ER 1079.

99 National Crime Agency v Robb [2014] EWHC 4384 (Ch). See also two decisions of Millett J: El Ajou v Dollar Land Holdings plc [1993] 3 All ER 717 (Ch), and Lonhro plc v Fayed (no 2) [1992] 1 WLR 1, 12. For a case where the claimant could trace into the proceeds of a successful investment, see: Trustee of the Property of F C Jones v Jones [1997] Ch 159 (CA).

100 Examples include: William Lacey (Hounslow) Ltd v Davis [1957] 2 All ER 712 (QBD); British Steel Corp v Cleveland Bridge and Engineering Co Ltd [1984] 1 All ER 504 (QBD); Rover International Ltd $v$ Cannon Film Sales Ltd (No 3) [1989] 3 All ER 423 (CA). The unjust factors were failure of basis or mistake.
} 
iour. ${ }^{101}$ The case law already acknowledges, for example, that where a contract is void for statutory transgression, the result usually cannot be side-stepped by suing for payment in unjust enrichment instead. ${ }^{102}$ So whether in contract law, or in unjust enrichment in the absence of a contract, a claimant should not be paid for their criminal behaviour.

(2) In another context, unjust enrichment seeks to reverse a transaction which was compromised by an unjust factor. ${ }^{103}$ In these circumstances, historically the claimant could not recover if the transaction was tainted by illegality (although the general rules was subject to a number of exceptions). For example, a claimant previously could not recover an unsuccessful bribe, ${ }^{104}$ or a 'donation' which sought to procure a civic honour. ${ }^{105}$

The position is now different. In Patel $v$ Mirza, ${ }^{106}$ the claimant paid money to the defendant, to be invested pursuant to a criminal scheme of insider dealing. The insider information was never forthcoming, so the claimant sought to recover his money. He was allowed to do so. The point made was this. The claimant was seeking to reverse the transaction. The refund would return the parties to the status quo ante, i.e. their positions prior to any criminality. ${ }^{107}$ In similar vein, a recipient might now have to return their bribe, ${ }^{108}$ and an assassin return their fee. ${ }^{109}$ Whether there are any other consequences for their criminal behaviour would be a matter for the criminal law. ${ }^{110}$

What this means is that, where a party seeks to undo a transaction, and thereby recover past payments in unjust enrichment, the fact that the transaction was criminal might never be relevant, because the very purpose of the action is to reverse the criminality and restore the parties to their previously legal positions. Similarly,

${ }_{101}$ The coherence rationale for the defence of illegality in unjust enrichment is also accepted by Virgo (2016).

102 Dimond v Lovell [2002] 1 AC 384 (HL), 397-398; Barons Finance Ltd v Makanju [2013] EWHC $153(\mathrm{Ch})$.

${ }^{103}$ Examples include: Wilkinson v Lloyd (1845) 7 QB 27; Greenwood v Bennett [1973] QB 195 (CA). Again the unjust factors were failure of basis or mistake. The authors of Goff \& Jones suggest that illegality is an unjust factor, a ground for restitution enabling the claimant to complete their cause of action and sue in unjust enrichment: Mitchel et al (2016: ch 25). Virgo (2018: 224-230) seems to suggest that illegality is not itself an unjust factor, but rather that a contract unenforceable for illegality reveals there to be a 'failure of legal basis', which he says is a ground for restitution: Either way, that is about illegality as founding or explaining a cause of action in unjust enrichment, whereas we are here concerned with how illegality operates as a defence in unjust enrichment. Similarly, in tort law, we need to distinguish between denying a duty to take care of the person acting illegally, as in Vellino $v$ Chief Constable of Manchester Police [2001] EWCA Civ 1249, and illegality as a defence properly so called: Goudkamp (2013: 126).

104 Nayyar v Denton Wilde Sapte [2009] EWHC 3218 (QB).

105 Parkinson v College of Ambulance Ltd [1925] 2 KB 1 (KBD).

106 [2016] UKSC 42.

107 [2016] UKSC 42, [154] (Lord Neuberger), [202] (Lord Mance).

108 [2016] UKSC 42, [118] (Lord Toulson).

109 [2016] UKSC 42, [176] (Lord Neuberger), [254] (Lord Sumption).

${ }^{110}$ Grabiner (2017: 20-21) suggests that this demarcates a bright line between civil and criminal law. 
because the transaction is undone, nor does it have anything to do with (the forwardlooking idea of) profiting from one's own wrong. There is no need for a defence of illegality.

Thus the defence of illegality in unjust enrichment is streamlined. If the claimant seeks to be paid for their actions, this is precluded where those actions are prohibited by the criminal law. But if the claimant seeks a refund, then even if their payment was pursuant to a criminal transaction, still the criminality is irrelevant.

With this in mind, there are two final cases to discuss:

In Hounga $v$ Allen, ${ }^{111}$ the claimant was employed as a home help by the defendant, but she was paid nothing and then evicted. The claimant had knowingly immigrated illegally, with the complicity of the defendant. It was held that the claimant could not succeed on her claim for unfair dismissal or unpaid wages because her contract of employment was illegal as contrary to statute. ${ }^{112}$ But she succeeded in her tortious claim for damages for racial discrimination. Comments in Patel v Mirza also suggested she might have recovered payment for her services in unjust enrichment. ${ }^{113}$ There are three points to make here.

First, O'Sullivan (2018: 179-184) questions whether the statute, properly interpreted, did preclude the claimant from suing in contract. In the later case of Okedina $v$ Chiakale, ${ }^{114}$ the court held that an illegal immigrant could sue in contract after all, at least when they had innocently outstayed their visa (the employer had concealed this from the employee). Second, the claimant in Hounga $v$ Allen recovered in tort, so here is yet another example that the defence of illegality has little role to play where the tortious claimant seeks compensation for harm suffered. Third, illegality might deny a contract, but a claim in unjust enrichment might still succeed because it is based on different conduct which does not transgress any prohibition. This brings us to our next case.

In Mohamed $v$ Alaga \& $C o,{ }^{115}$ the claimant had an agreement with the defendant to share the defendant's legal fees. That was unenforceable for transgressing regulation. ${ }^{116}$ That did not stop the claimant suing successfully, not for a share of the fees, but on a quantum meruit for the services they had rendered. Those services (such as translation services) were perfectly lawful.

\footnotetext{
111 [2014] UKSC 47.

112 Immigration Act 1971, s 24B.

113 [2016] UKSC 42, [119] (Lord Toulson), [243] (Lord Sumption).

114 [2019] EWCA Civ 1393.

115 [1999] 3 All ER 699 (CA), endorsed in Patel v Mirza [2016] UKSC 42, [119] (Lord Toulson).

116 Solicitors' Practice Rules 1990, r 7; Solicitors Act 1974, s 31.
} 


\section{Trusts}

Previously, the defence of illegality, as it applied to the law of trusts, turned on the reliance principle. For example, in Tinsley $v$ Milligan, ${ }^{117}$ two people contributed the purchase money for a house, which was put in the sole name of $\mathrm{T}$, so that $\mathrm{M}$ could fraudulently claim social security payments. When the relationship broke down, $\mathrm{M}$ sought to say that she had a beneficial share of the house. The court agreed: there was a presumed resulting trust, and $\mathrm{M}$ was able to provide evidence in support (e.g. her contribution to the purchase price), without needing to rely on the illegal plan. However, in Patel $v$ Mirza, the court said that the reliance principle in Tinsley $v$ Milligan should no longer be followed. ${ }^{118}$ It would seem that Lord Toulson's trio of considerations approach should apply instead.

The Law Commission said that the illegality defence, as it applied to trusts, produced arbitrary results. ${ }^{119}$ It recommended that the illegality defence should apply to trusts created in order to conceal beneficial ownership for a criminal purpose. ${ }^{120}$ (I agree.) It said that, once the illegality defence was engaged, whether or not it succeeded should depend on the court's discretion, applying a range of factors, and to this end a draft bill was proposed. The legislature decided not to take this forward, but Patel $v$ Mirza does of course apply a discretionary approach which weighs up a trio of considerations.

One of the factors recommended by the Law Commission was whether enforcing the trust would further or defeat the criminal purpose. ${ }^{121}$ In my view, this should be the only relevant question. This follows when we accept the first two premises. First, the purpose of the illegality defence is to ensure that what is forbidden in the criminal law is not furthered in private law. Second, the illegality defence in trusts law is only engaged when the trust was created in order to conceal ownership for a criminal purpose. It then follows that the trust should be enforced or denied so as to ensure that the criminal purpose is defeated. In this way, trusts law would stand shoulder to shoulder with criminal law enforcement and prevention. There should be no residual grounds for enforcing or denying the trust, if to do so would further the criminal purpose, because this would undermine the criminal law and the very purpose of the illegality defence.

Thus in trusts law, as in contract law, there is no need for a discretionary approach. Hard-edged rules can do the job. In trusts law, the test might be as follows. Was the trust created in order to conceal ownership for a criminal purpose? If so, the trust should be enforced or denied so as to defeat that criminal purpose.

To see how this works in practice, let us apply it to the facts of Tinsley $v$ Milligan.

In Tinsley $v$ Milligan, the outcome under this proposed approach would be the same. The trust was created for the criminal purpose of making fraudulent claims

\footnotetext{
117 [1994] 1 AC 340 (HL).

118 [2016] UKSC 42, [110] (Lord Toulson).

119 Law Com No 320, The Defence of Illegality (2010), [2.13].

120 Law Com No 320, The Defence of Illegality (2010), [2.32].

121 Law Com No 320, The Defence of Illegality (2010), [2.73].
} 
on social security. That purpose would be defeated by upholding the trust. How so? If instead no trust was recognised, then $M$ would have been exculpated, since the claims on social security would have been legitimate, because she would not have had any other assets after all. This would defy reality, given that both $\mathrm{T}$ and $\mathrm{M}$ admitted to the criminal plan. And it would give $\mathrm{T}$ a windfall, by giving her sole beneficial ownership of the house, which would hardly deter people from following T's example of facilitating fraud. In contrast, with the trust upheld, it confirms that $\mathrm{M}$ was acting criminally, and criminal law is now able to visit the consequences of that upon $\mathrm{M},{ }^{122}$ who now also has the assets to reimburse their fraudulent receipts.

\section{Conclusion}

The principal criticism of Lord Toulson's trio of considerations approach in Patel to the defence of illegality is that it is vague. It might provide the court with some generic headings to frame their discussion in any given case after the litigation has arisen, but it gives very little concrete guidance to citizens to predict their legal rights in advance. This is compounded by the fact that: the third consideration, on proportionality, involves a non-exhaustive list of further factors to weigh up; and the first consideration, about the prohibition transgressed, was expanded in Henderson to consider two further policies, namely public opinion and deterrence. This suggests that the trio of considerations are not yet settled, and might come to include further policies not yet identified. Nor does it help that the new additions of public opinion and deterrence are questionable in themselves.

The defence of illegality articulated in Patel purports to apply across the board to all civil claims. No doubt this requires a level of generality which tends towards vagueness. But there is no need for a one size fits all approach. We can maintain coherence by having a singular rationale underpinning the defence, but then allow that rationale to manifest in different concrete rules in different areas of law.

What is that rationale? The notion of not profiting from one's own wrong was given a lukewarm reception by Lord Toulson in Patel as lacking explanatory power and providing poor guidance. It is irrelevant in tort law, at least where a claimant seeks compensation for harm suffered, and irrelevant in unjust enrichment where a claimant seeks to reverse a transaction. It was seemingly discarded in Stoffel, but rehabilitated in Henderson. It ought to be rejected. So too ought the suggestion in tort law that illegality precludes us from identifying a suitable standard of care.

Much the best rationale, identified in Patel and given as the sole justification in Stoffel, is the notion that the law should be coherent and not self-defeating. This is a sound maxim, but we can still proceed to a much more useful level of specificity in the context of the defence of illegality: if conduct is proscribed by the criminal law, then private law should not enforce that conduct, or reward it with payment. Put that precisely, it guides the formulation of the defence in each different area of

122 In particular, the Proceeds of Crime Act 2002 might be relevant here. See too: Law Com No 320, The Illegality Defence (2010), [2.44]. 
law. It also renders redundant the further rationale of not profiting from one's wrong, because any residual area where that rationale might have applied, like contract, is now subsumed into the coherence rationale.

So what are those concrete formulations of the defence? They are as follows.

In tort law, there is no need for the defence, at least where a claimant seeks compensation for harm suffered. Suitable outcomes are already achieved: through defences like contributory negligence and volenti; or by acknowledging that the cause of action is not made out, on account of the loss being too remote, or the claimant's own conduct being an intervening cause of the harm they suffer.

In contract law, the defence of illegality should be distinguished from the doctrine of restraint of trade, and the exercise of statutory interpretation. It should respond to conduct prohibited by the criminal law, and not a judge's sense of subject-matter immorality. Thereafter, the defence of illegality can be formulated with precision. Where a claimant seeks specific performance of a contract, or seeks compensation to put them in the same position as if the contract had been performed, then the contract or contract term should be unenforceable if it: (i) requires criminal conduct; or (ii) was created for criminal purposes. Any other illegality is peripheral and should have no impact on the contract.

In unjust enrichment, where a claimant seeks to be paid for their conduct, this should be precluded where that conduct is prohibited by the criminal law. That is the streamlined remit for a defence of illegality. Otherwise, where the claimant seeks a refund, then even if their payment was pursuant to a criminal transaction, nevertheless the criminality is irrelevant, as is any defence of illegality. As Patel demonstrates, this is because the effect of the claim is to reverse the transaction, and restore the parties to their previous lawful positions.

In trusts law, the defence could be expressed as follows. Was the trust created in order to conceal ownership for a criminal purpose? If so, the trust should be enforced or denied so as to defeat that criminal purpose. There should otherwise be no residual discretion or consideration to uphold a trust which thereby furthers a criminal purpose.

None of this precludes the claimant from suffering other consequences as a result of their criminal conduct, including prosecution, or the forfeiture of assets as proceeds of crime.

\section{Declarations}

Conflict of interest The author states that there is no conflict of interest.

Open Access This article is licensed under a Creative Commons Attribution 4.0 International License, which permits use, sharing, adaptation, distribution and reproduction in any medium or format, as long as you give appropriate credit to the original author(s) and the source, provide a link to the Creative Commons licence, and indicate if changes were made. The images or other third party material in this article are included in the article's Creative Commons licence, unless indicated otherwise in a credit line to the material. If material is not included in the article's Creative Commons licence and your intended use is not permitted by statutory regulation or exceeds the permitted use, you will need to obtain permission directly from the copyright holder. To view a copy of this licence, visit http://creativecommons.org/licen ses/by/4.0/. 


\section{References}

Buckley, Richard. 2015. Injured passengers and the defence of illegality. Common Law World Review 44: 192-202.

Burrows, Andrew. 2020. A restatement of the english law of contract. Oxford: Oxford University Press.

Dworkin, Ronald. 1978. Taking rights seriously. Cambridge: Harvard University Press.

Glofcheski, Rick. 1999. Plaintiff's illegality as a bar to recovery of personal injury damages. Legal Studies 19: 6-23.

Goudkamp, James. 2011. Ex Turpi Causa and immoral behaviour in the tort context. Law Quarterly Review 127: 354-358.

Goudkamp, James. 2013. Tort law defences. Oxford: Hart.

Goudkamp, James. 2017. The end of an era? Illegality in private law in the supreme court. Law Quarterly Review 133: 14-20.

Grabiner, Anthony. 2017. Illegality and restitution explained by the supreme court. Cambridge Law Journal 76: 18-21.

Green, Sarah. 2018. Illegality and zero sum torts. In Illegality after Patel v Mirza, ed. Sarah Green and Alan Bogg. Oxford: Hart.

Hart, H.L.A. 1963. Law, liberty, and morality. Redwood City: Stanford University Press.

Jones, Michael, and Anthony Dugdale. 2020. Clerk \& Lindsell on torts. London: Sweet \& Maxwell.

Kudhail, Tirath. 1999. Should prostitution be legalised? UCL Jurisprudence Review 6: 165-190.

Law Commision. 1999. Illegal transactions: the effect of illegality on contracts and trusts. CP No 154.

Law Commission. 2001. The illegality defence in tort. CP No 160.

Law Commission. 2009. The illegality defence. CP No 189.

Law Commission. 2010. The illegality defence. Law Com No 320.

Mitchel, Charles, et al. 2016. Goff \& Jones: the law of unjust enrichment. London: Sweet \& Maxwell.

Moen, Ole Martin. 2014. Is prostitution harmful? Journal of Medical Ethics 40: 73-81.

O'Sullivan, Janet. 2018. Illegality and contractual enforcement after Patel v Mirza. In Illegality after Patel v Mirza, ed. Sarah Green and Alan Bogg. Oxford: Hart.

Primoratz, Igor. 1993. What's wrong with prostitution? Philosophy 68: 159-182.

Virgo, Graham. 2016. The defence of illegality in unjust enrichment. In Defences in unjust enrichment, ed. Andrew Dyson, et al. Oxford: Hart.

Virgo, Graham. 2018. Illegality and unjust enrichment. In Illegality after Patel v Mirza, ed. Sarah Green and Alan Bogg. Oxford: Hart.

Publisher's Note Springer Nature remains neutral with regard to jurisdictional claims in published maps and institutional affiliations. 